\title{
The Effect of School Leadership, Academic Supervision, and Work Motivation on Teacher Performance
}

\author{
Mustahyi $^{1^{*}}$, Joni Rohkmat ${ }^{1,2,3}$, Fahruddin ${ }^{1}$ \\ 1 Department of Education Administration, Postgraduate Program, Universitas Mataram, Indonesia \\ 2 Department of Physics Education, Faculty of Teacher Training and Education, Universitas Mataram, Indonesia \\ ${ }^{3}$ Department of Science Education, Postgraduate Program, Universitas Mataram, Indonesia. \\ Corresponding Author Email: mustahyi@unram.ac.id
}

\author{
Article Info \\ Received: 15 Oktober 2021 \\ Revised: 27 September 2021 \\ Accepted: 30 September 2021
}

\begin{abstract}
This study aims to examine the effect of principal leadership, academic supervision, and work motivation on teacher performance. The method used is a survey method with a quantitative correlational approach. The research sample consisted of 136 teachers (86 male teachers and 50 female teachers) from 4 State Senior High Schools in East Lombok Regency, namely SMA Negeri 1 Aikmel, SMA Negeri 1 Wanasaba, SMA Negeri 1 Pringgabaya, and SMA Negeri 1 Suela. The research instrument in the form of a questionnaire was given to respondents directly after testing the validity and reliability. The data analysis technique used a simple regression test and multiple regression tests followed by a correlation test. Data analysis results based on the coefficient of determination for each research variable on teacher performance obtained the coefficient of determination of work motivation of $47.8 \%$, academic supervision of $45.5 \%$, and the variable of principal leadership of $44.4 \%$. While the results of the coefficient of determination collectively were $53.8 \%$. Thus, it can be concluded that both individually and collectively, the principal's leadership, academic supervision, and work motivation affect teacher performance.
\end{abstract}

Keywords: Principal leadership; academic supervision; work motivation; teacher performance

Sitasi: Mustahyi, M., Joni Rohkmat, J., \& Fahruddin, F. (2021). The Effect of School Leadership, Academic Supervision, and Work Motivation on Teacher Performance. ALEXANDRIA (Journal of Economics, Business, E Entrepreneurship), 2(2), 5357. doi:https://doi.org/10.29303/alexandria.v2i2.13

\section{Introduction}

Education is the primary capital to create superior Human Resources (HR) (Cintamulya, 2015). As an institution in the world of education, schools have a vision, mission, and goals. Mission development and vision realization in achieving national education goals require professional teachers (Noorjannah, 2014). Teachers are one of the elements of resources that determine success in schools (Amran, 2015); (Nurhaidah, 2014). In this case, the government has a high commitment to improving the quality of education. Improving the quality of education is determined by the readiness of human resources involved in the education process itself. Therefore, in improving their performance, teachers must have professional abilities and skills (Feralys, 2015).

Given the importance of teachers' position, role, and function as teaching staff, optimal performance is needed to improve quality human resources (Lailatussaadah, 2015). Teachers always have to develop their potential, open insights, increase their knowledge, and always look for the latest information about learning methods and learning media. The teacher is a resource element that is critical to the success of education in schools (Widianstah, 2018) because the teacher is a human element that is very closely related to students in daily education efforts at school (Musa, 2016); (Nurhayati, 2015). The person responsible for the implementation of the learning process in the classroom is the teacher. The empowerment of teacher quality needs to be carried out continuously and sustainably (Setiawan, 2019).

The learning achievement of high school students in East Lombok Regency can be seen from the national exam results in the last two years showing that achievement is still low. In 2018, the average national exam score for SMA in East Lombok Regency was 
45.48, while in 2019, the average national exam score for SMA in East Lombok Regency was 48.18. The average national exam results for the last two years are still below the national standard, namely 5.50. It shows that the achievement of high school national exam scores in East Lombok Regency is still low

The results of interviews with the head of the workforce division of the Education and Culture Office of East Lombok Regency stated that the teacher performance of the 1,669 public high school teachers spread across East Lombok Regency had not yet reached the target set. Meanwhile, the Head of the Education and Culture Branch for East Lombok Regency targets SMA Negeri Lombok Timur Regency teachers' performance at 91.00 . In 2018, the average teacher performance appraisal was 85.99, and in 2019 the average teacher performance appraisal was 87.11. It means that teachers' average performance value in the last two years needs to be improved and developed to improve student achievement.

Student achievement scores do not only measure teacher performance but also is influenced by other factors such as infrastructure (Fudin, 2020); (Sutama, Kristiawanto, \& Suyatmini, 2016), the school environment (Zuhriyah, 2016), motivation (Setiawan, 2019) and the talents and interests of students. In this case, the role of the principal is needed to improve teacher performance. As the education unit (school), the principal is responsible for the effectiveness and evaluation of learning in schools through the principal's supervision program.

The principal has a supervisory competency that includes planning an academic supervision program to increase teacher professionalism (Selvia, 2015). Implementing the academic supervision of teachers must use the right techniques and approaches (Karwati, 2019). The results of the supervision must be followed up in order to increase teacher professionalism and work motivation

Motivation at work is something a teacher must have in carrying out the mandate of national education (Dewi, 2018). Teachers who have high work motivation will always work hard to overcome all kinds of problems faced to achieve good work results. The work motivation of East Lombok State Senior High School teachers can be improved by providing guidance, direction, motivation, role models, and advice to students

Based on the description above, the researcher has researched. "The Influence of Principal Leadership, Academic Supervision and Work Motivation on the Performance of Public High School Teachers in East Lombok Regency".

\section{Method}

The research subjects were teachers of SMA Negeri in East Lombok Regency, namely at SMAN 1 Aikmel, SMAN 1 Wanasaba, SMAN 1 Pringgabaya, and SMAN 1 Suela. This study uses a survey method with a quantitative correlational approach, which is part of the ex-post facto research. The study population was teachers of SMA Negeri in East Lombok Regency, namely SMA Negeri, totaling 209 teachers. The sample consisted of 136 teachers (86 male teachers and 50 female teachers) scattered in SMA Negeri 1 Aikmel, SMA Negeri 1 Wanasaba, SMA Negeri 1 Pringgabaya, and SMA Negeri 1 Suela. Sampling using a Probability Sampling technique

The data taken in this study are primary data obtained by measuring the variables with data collection methods and through questionnaires given to respondents directly. The research instrument used as a measuring tool for research variables is a questionnaire containing some statement items arranged on a Likert scale with four alternative answers: 1 ) disagree; 2) less disagree; 3) agree, and 4) strongly agree. Statement score: score 1 = disagree, score 2 = less disagree, score 3 $=$ agree, and score $4=$ strongly agree

This study uses simple regression analysis and multiple regression, which is used to determine the accuracy of the relationship between teacher performance (dependent variable) and principal leadership, academic supervision, and work motivation as influencing variables (independent variable) with the equation:

$$
\mathrm{Y}=\mathrm{a}+\mathrm{b}_{1} \mathrm{X}_{1}+\mathrm{b}_{2} \mathrm{X}_{2}+\mathrm{b}_{\mathrm{a}} \mathrm{X}_{\mathrm{a}}
$$

Where:

$\mathrm{Y}=$ Teacher performance

$\mathrm{a}=$ Regression Constant

b1 = Principal leadership regression coefficient

b2 = Academic Supervision regression coefficient

b3 $=$ Work Motivation regression coefficient

X1 = Principal Leadership

$\mathrm{X} 2$ = Academic Supervision

X3 $=$ Work Motivation.

\section{Hasil dan Pembahasan}

The formulation of the hypothesis for the effect of principal leadership (X1), academic supervision (X2), and work motivation $(\mathrm{X} 3)$ on teacher performance $(\mathrm{Y})$ is $\mathrm{H} 0: \beta=0$. It means that there is no influence between principal leadership (X1), academic supervision (X2), and work motivation $(\mathrm{X} 3)$ together on the performance of teachers (Y) SMA Negeri in East Lombok Regency. From the results of multiple regression analysis, it was 
found that the influence of school principal leadership $(\mathrm{X} 1)$, academic supervision (X2), and work motivation
(X3) on the performance of public high school teachers in East Lombok Regency is presented in Table 1.

Table 1. Multiple Regression Test Results for Principal Leadership, Academic Supervision, Work Motivation on Performance of Public High School Teachers in East Lombok Regency

\begin{tabular}{|c|c|c|c|c|c|c|}
\hline \multirow{2}{*}{\multicolumn{2}{|c|}{ Model }} & \multicolumn{3}{|c|}{$\begin{array}{r}\text { Unstandardized Coefficients Standardized } \\
\text { Coefficients }\end{array}$} & \multirow[t]{2}{*}{$\mathrm{t}$} & \multirow[t]{2}{*}{ Sig. } \\
\hline & & B & Std. Error & Beta & & \\
\hline \multirow[t]{4}{*}{1} & (Constant) & 13.636 & 7.949 & & 1.716 & .089 \\
\hline & Principal Leadership & -.130 & .154 & -.140 & -.840 & .402 \\
\hline & Academic Supervision & .464 & .126 & .418 & 3.695 & .000 \\
\hline & Work motivation & .571 & .148 & .505 & 3.852 & .000 \\
\hline
\end{tabular}

Based on the calculation results, the regression direction coefficient b1 is -0.130 , the regression direction b2 is 0.464 , the regression direction b3 is 0.571 , and the constant (intercept) a is 13.636. Thus, the form of influence between principal leadership (X1), academic supervision $(\mathrm{X} 2)$, and work motivation $(\mathrm{X} 3)$ teacher performance $(\mathrm{Y})$ is shown by the equation $\hat{\mathrm{Y}}=$ 13.636- $0.130 \mathrm{X}_{1}+0.464 \mathrm{X}_{2}+0.571 \mathrm{X}_{3}$. Test results and linearity are shown in Table 2.

Table 2. The Results of Significance and Linear Leadership of Principals for Academic Supervision of Work Motivation and Teacher Performance

\begin{tabular}{llrrrrr} 
Model & & Sum of Squares & df & Mean Square & F & Sig. \\
\hline 1 & Regression & 2675.090 & 3 & 891.697 & 51.146 & $.000^{\mathrm{a}}$ \\
& Residual & 2301.352 & 132 & 17.434 & & \\
& Total & 4976.441 & 135 & & & \\
\hline
\end{tabular}

From the calculation results in Table 2, the Sig. = $0.000<0.05$. Thus, it can be concluded that $\mathrm{H} 0$ which states the regression equation, $\hat{Y}=13.636-0.130 \mathrm{X}_{1}+$ $0.464 \mathrm{X}_{2}+0.571 \mathrm{X}_{3}$ is not significantly rejected and the results of the linearity hypothesis which state that regression is not linear are rejected. Based on these results, the equation $\hat{Y}=13,636-0,130 X_{1}+0.464 X_{2}+$ $0.571 \mathrm{X}_{3}$ is significant and linear.

Thus, the understanding contained in the equation $\hat{Y}=$ $13.636-0.130 \mathrm{X}_{1}+0.464 \mathrm{X}_{2}+0.571 \mathrm{X}_{3}$ is a change in one unit of perception on principal leadership (X1), and other factors are considered constant, will be followed by changes in teacher performance $(\mathrm{Y})$ of -0.130 units on the intercept of 13.636. Meanwhile, one unit change in academic supervision (X2) and other factors is considered constant, will be followed by changes in teacher performance $(\mathrm{Y})$ of 0.464 at an intercept (constant) of 13.636, and also a change of one unit in work motivation (X3) and other factors considered constant, it will be followed by changes in teacher performance $(\mathrm{Y})$ of 0.571 in the intercept (constant) of 13.636. Furthermore, the results of multiple correlation tests between principal leadership (X1), academic supervision $(\mathrm{X} 2)$, and work motivation (X3) teacher performance $(\mathrm{Y})$ are presented in Table 3.

Table 3. Significance Test Results for Multiple Correlation Coefficients between Principal Leadership (X1), Academic Supervision (X2) and Work Motivation (X3) on Teacher Performance (Y)

\begin{tabular}{|c|c|c|c|c|c|c|c|c|c|}
\hline \multirow[b]{2}{*}{ Model } & & \multirow[b]{2}{*}{ R Square } & \multirow[b]{2}{*}{$\begin{array}{l}\text { Adjusted R } \\
\text { Square }\end{array}$} & \multirow[b]{2}{*}{$\begin{array}{l}\text { Std. Error of } \\
\text { the Estimate }\end{array}$} & \multicolumn{5}{|c|}{ Change Statistics } \\
\hline & & & & & $\begin{array}{l}\text { R Square } \\
\text { Change }\end{array}$ & F Change & df1 & df2 & $\begin{array}{l}\text { Sig. F } \\
\text { Change }\end{array}$ \\
\hline 1 & $.733^{a}$ & .538 & .527 & 4.17546 & .538 & 51.146 & 3 & 132 & .000 \\
\hline
\end{tabular}

The data in Table 3 above shows that the multiple correlation coefficient (ry123) is 0.733 , which can be expressed in a strong correlation with sig. 0,000. Thus, it can be concluded that there is a joint correlation between principal leadership (X1), academic supervision $(\mathrm{X} 2)$, and work motivation $(\mathrm{X} 3)$ on teacher performance $(\mathrm{Y})$. The table above also provides information on the magnitude of the joint influence between principal leadership (X1), academic supervision (X2), and work motivation (X3) with 
teacher performance $(\mathrm{Y})$ based on the $\mathrm{R}$ Square value (determination value) of $($ ry1232 $)=(0.7332)=0.538$. The determination value of 0.538 means that $53.8 \%$ of the joint influence between principal leadership (X1), academic supervision (X2), and work motivation (X3) affects the performance of public high school teachers in East Lombok Regency while other factors influence the rest.

The results of testing the fourth hypothesis can be found that there is a significant effect of principal leadership, academic supervision, and work motivation together on the performance of state high school teachers in East Lombok Regency. These results indicate that the better the principal's leadership, academic supervision, and work motivation, the better the performance of SMA Negeri teachers in East Lombok Regency. This means that to improve the performance of public high school teachers in East Lombok Regency, it is very important to pay attention to the leadership of the principal, academic supervision, and work motivation.

The performance of public high school teachers in East Lombok Regency is that their overall success rate is influenced by leadership management in motivating and supervising teachers and preparing other facilities and facilities that support increased teacher performance. Supardi (2016) explains that many factors affect performance, including environment, management behavior, job design, performance appraisal, feedback, and wage administration. Saerozi (2005) suggests that several factors can affect teacher performance in carrying out their duties, namely: 1) the leadership of the principal, 2) work facilities; 3) expectations; 4) trust in school personnel, and 5) encouragement or motivation. Thus it appears that the principal's leadership and work motivation will determine whether or not teacher performance is good.

Improving public high school teachers' performance in the East Lombok Regency is very important because their good performance will help schools improve the quality of education. Many factors can be done in improving the performance of public high school teachers in East Lombok Regency, but in this study, three important factors can improve their performance, namely the principal's leadership, academic supervision, and work motivation on the performance of public high schools in East Lombok Regency of $53,8 \%$. This percentage shows quite good results, which can prove that the leadership of the principal of academic supervision and work motivation has a significant role in improving the performance of public high school teachers in East Lombok Regency.

This study indicates that work motivation has the greatest contribution among the three independent variables in improving the performance of SMA Negeri teachers in East Lombok Regency. Uno (2016) explained that work motivation is an impetus from within and from the outside of a person to do something that is visible from the internal and external dimensions. Winardi (2002) explains that work motivation is a potential strength that exists in a human being, which can be developed by a number of outside forces which essentially revolve around monetary rewards and non-monetary rewards that can affect performance results positively or negatively, depending on the situation and conditions faced by the person concerned. Ilyas (2002) argues that work motivation is something that comes from the internal of an individual that creates an encouragement or enthusiasm to work hard.

When viewed from the correlation test results both individually and collectively, the three independent variables are categorized as strong correlation with the interval between 0.60 to 0.799 . Among these three variables, the work motivation variable gave the highest contribution to influence with a determination coefficient of $47.8 \%$ and successively followed by the academic supervision variable with a determination coefficient of $45.5 \%$, and the lowest principal leadership variable with a determination coefficient of $44.4 \%$. This is in accordance with the conceptual framework that teacher performance is influenced by two factors (Mangkunegara, 2009), namely individual factors (motivation that comes from within the teacher itself) and environmental factors, the work climate, and harmonious relationships between teachers and school principals.

To see the effect of each variable individually accompanied by the influence of other variables can be described as follows: 1) on the work motivation variable (X3), the coefficient of determination obtained is $47.8 \%$, and the remaining $52.2 \%$ is influenced by variables X1, X2, and other variables; 2 ) in the academic supervision variable $(\mathrm{X} 2)$, the coefficient of determination obtained is $45.5 \%$, and variables $\mathrm{X} 1, \mathrm{X} 3$ influences the remaining $54.5 \%$, and other variables; and 3 ) in the principal leadership variable, the coefficient of determination obtained is $44.4 \%$, and the remaining $55.6 \%$ is influenced by variables $\mathrm{X} 2, \mathrm{X} 3$, and other variables.

However, when this independent variable is collaborated to help improve teacher performance effectiveness, it will have an even greater influence. The correlation test results of 0.733 compared to each of the independent variables with a determination coefficient of $53.8 \%$. This affects contributing together in realizing better teacher performance. 


\section{Conclusion}

Based on the research results, it can be concluded that: Principal leadership, academic supervision, and work motivation influence the performance of public high school teachers in East Lombok Regency. The principal's leadership style made a positive contribution to teacher performance by $44.4 \%$, the culture of academic supervision made a positive contribution to teacher performance by $45.5 \%$, and work motivation made a positive contribution to teacher performance by $47.8 \%$. Together the principal's leadership, academic supervision, and work motivation contributed positively to teacher performance by $53.8 \%$, while other factors determined $46.2 \%$ of the teacher performance variables.

\section{References}

Amran. (2015). Faktor penentu keberhasilan pengelolaan satuan pendidikan. Jurnal Manajer Pendidikan, 9(2), 185-196. Retrieved from https://ejournal.unib.ac.id/index.php/manajerp endidikan/article/view/1113/922

Cintamulya, I. (2015). Peranan Pendidikan dalam Memepersiapkan Sumber Daya Manusia di Era Informasi dan Pengetahuan. Formatif: Jurnal Ilmiah Pendidikan MIPA, 2(2), 90-101. https://doi.org/10.30998/formatif.v2i2.89

Dewi, R. S. (2018). Kemampuan Profesional Guru Dan Motivasi Kerja Terhadap Kinerja Mengajar Guru Sekolah Dasar. Jurnal Administrasi Pendidikan, 25(1), 150-159. https://doi.org/10.17509/jap.v25i1.11581

Feralys, N. M. (2015). Kompetensi Guru Dalam Peningkatan Prestasi Belajar Pada Smp Negeri Dalam Kota Banda Aceh. Jurnal Administrasi Pendidikan: Program Pascasarjana Unsyiah, 3(1), 45-67.

Fudin, A. (2020). Pengaruh Sarana Prasarana Terhadap Kinerja Guru. Manajemen Pendidikan, 15(1), 711. https://doi.org/10.23917/mp.v15i1.10611

Karwati, W. (2019). Guru Sdn Santaka Kecamatan Cimanggung Dalam Melaksanakan Standar Proses. Jurnal Pedagogik Pendidikan Dasar, 6(1), 41-97.

Lailatussaadah, L. (2015). Upaya Peningkatan Kinerja Guru. Intelektualita, 3(1), 243106.

Mangkunegara, A,. P. 2009. Evaluasi Kinerja Sumber Daya Manusia. Bandung: Refika Aditama

Musa, M. I. (2016). Pengembangan Kompetensi Guru Terhadap Pelaksanaan Tugas Dalam Mewujudkan Tenaga Guru Yang Profesional. Jurnal Pesona Dasar, 2(4), 8-27.

Noorjannah, L. (2014). Pengembangan Profesionalisme
Guru Melalui Penulisan Karya Tulis Ilmiah Bagi Guru Profesional Di Sma Negeri 1 Kauman Kabupaten Tulungagung. Jurnal Humanity, 10(1), 11406.

Nurhaidah. (2014). Kompetensi Guru, Sumber Daya, Berkualitas. Jurnal Pesona Dasar, 2(3), 13-26.

Nurhayati, N. (2015). Perbedaan Pengaruh Fungsi Guru (Guru Bidang Studi dengan Guru Kelas) terhadap Hasil Belajar Matematika Ditinjau dari Tingkat IQ Siswa. Formatif: Jurnal Ilmiah Pendidikan MIPA, 4(2), 140-149. https://doi.org/10.30998/formatif.v4i2.148

Saerozi, M. 2005. Manajemen Sekolah. Yogyakarta: Ar Ruzz

Selvia. (2015). Implementasi supervisi akademik kepala sekolah dalam peningkatan profesionalisme guru. Manajer Pendidikan, 9(21), 43-49.

Setiawan, D. (2019). Pemberdayaan Guru dalam Meningkatkan Kualitas Pembelajaran di SLB. Journal Of Education Management \& Administration Review, 2(1), 177-182. Retrieved from

https://jurnal.unigal.ac.id/index.php/ijemar/ar ticle/view/1820

Supardi. 2014. Aplikasi Statistika Dalam Penelitian: Konsep Statistika YangLebih Komprehensif. Jakarta: Prima Ufuk Semesta.

Sutama, Kristiawanto, \& Suyatmini. (2016). Kontribusi Sarana Prasarana Pendidikan, Kondisi Lingkungan, Kedisiplinan Kerja Terhadap Kinerja Guru SD. Jurnal Managemen Pendidikan, 11(2), 91-102.

Uno, H., B.2014. Teori motivasi \& pengukurannya; analisis di bidan pendidikan. Jakarta: Bumi Aksara

Widianstah, A. (2018). Peranan Sumber Daya Pendidikan sebagai Faktor Penentu dalam Manajemen Sistem Pendidikan. Jurnal Humaniora Bina Sarana Informatika, 18(2), 229$234 . \quad$ Retrieved from http://ejournal.bsi.ac.id/ejurnal/index.php/cak rawala/article/view/4347

Winardi. 2002. Motivasi dan Pemotivasian dalam Manajeman. Jakarta: PT.Grafindo Persada

Zuhriyah, S. (2016). Faktor-Faktor Yang Mempengaruhi Kinerja Guru Smk Negeri Kelompok Pariwisata Di Daerah Istimewa Yogyakarta. LITERASI (Jurnal Ilmu Pendidikan), 6(2), 203. https://doi.org/10.21927/literasi.2015.6(2).203215. 